\title{
IDENTIFIKASI MOLEKULER DAN STATUS KONSERVASI IKAN PARI HIU (RHINIDAE) YANG DIDARATKAN DI PULAU BANGKA
}

\author{
Siti Aisyah ${ }^{\mathrm{a}, *}$ dan Arthur Muhammad Farhaby ${ }^{\mathrm{a}}$ \\ a Jurusan Manajemen Sumberdaya Perairan, Fakultas Pertanian, Perikanan, dan Biologi \\ Universitas Bangka Belitung \\ *Koresponden penulis: sitiaisyahsa057@gmail.com
}

\begin{abstract}
Abstrak
Tingginya aktivitas penangkapan Pari Hiu (Rhinidae) berpengaruh besar terhadap populasi dan keseimbangan ekosistem laut. Hal tersebut didukung dengan karakteristik Pari Hiu yang memiliki kemampuan reproduksi rendah, pertumbuhan yang lambat serta resiko kematian yang tinggi. Terbatasnya informasi basis data yang berhubungan dengan Pari Hiu dapat menurunkan pengawasan dan memengaruhi peraturan tentang jumlah penangkapan. Sehingga kondisi ini dikhawatirkan berdampak terhadap kelangsungan hidup Pari Hiu khususnya di Kepulauan Bangka Belitung. Salah satu basis data penting yang harus dilakukan yaitu identifikasi akurat untuk spesies ikan Pari Hiu sebagai acuan dalam penentuan status konservasi. Tujuan dari penelitian ini adalah identifikasi Pari Hiu dengan metode molekuler untuk mengetahui status konservasi dan perdagangan Pari Hiu yang didaratkan di Pulau Bangka. Sampel Pari Hiu diperoleh dari sumber pendaratan potensial di Pulau Bangka, yaitu Pelabuhan Perikanan Nusantara (PPN) Sungailiat, Tempat Pelelangan Ikan (TPI) Ketapang - Kota Pangkalpinang dan Tempat Pelelangan Ikan (TPI) Kurau - Kabupaten Bangka Tengah. Pelaksanaan penelitian terdiri dari tiga tahap yaitu pengumpulan sampel, identifikasi molekuler (mtDNA gen Cytochrome Oxidase Subunit 1/COI), dan status konservasi serta perdagangan Pari Hiu. Hasil pencocokan karakter nukleotida gen COI dengan menggunakan program BLAST yang terintegrasi pada laman GenBank menunjukkan bahwa ketiga sampel ikan Pari Hiu teridentifikasi sebagai spesies Rhina ancylostoma (Bloch and Schneider, 1801) (Bowmouth Guitarfish, Shark Ray) dengan tingkat kemiripan sebesar 100\%. Berdasarkan data IUCN Red List, spesies Rhina ancylostoma masuk dalam kategori Critically Endangered (CR) dan berdasarkan status perdagangannya, pada pertemuan CoP ke 18 di Geneva, Agustus 2019, CITES telah menambahkan Wedgefishes (Family Rhinidae) ke dalam Apendix II.
\end{abstract}

Keywords: Bangka, pari hiu, Rhina ancylostoma, identifikasi molekuler, status konservasi

\begin{abstract}
Excessive fishing of Shark Ray (Rhinidae) greatly affects its population and the balance of the marine ecosystem. This is supported by their relatively low fecundity, slow growth, and late maturity resulting in a low population growth rate. Lack of database information, relating to the Shark Ray can reduce oversight or regulations governing the production of the total catch. The current situation is feared to risk the survival of of Shark Ray, especially in Bangka Belitung Islands. The purpose of this research is to identify the molecular basis Shark Ray and the conservation status of the Shark Ray landed on Bangka Island. Shark Ray samples obtained from a source of potential landing in Bangka Island, namely PPN Sungailiat (Bangka Regency), TPI Ketapang (Pangkalpinang City) and TPI Kurau (Central Bangka Regency). The research method consists of three stages: collection of samples, the molecular identification (mtDNA Cytochrome Oxidase Subunit 1 / COI gene), phylogenetic analysis and conservation status of Shark Ray. The results of the COI gene nucleotide character matching were performed by using the BLAST program integrated into GenBank pages and showed that the three samples of Shark Rays were identified as Rhina Ancylostoma species (Bowmouth guitarfish, Shark Ray) with a rate of similarity of 100\%. Based on data from the IUCN Red List, the species Rhina Ancylostoma in the category of Critically Endangered (CR) and based on the status of trade, at the 18th CoP meeting in Geneva, on August 2019, CITES has added Wedgefishes (Family Rhinidae) in Appendix II.
\end{abstract}

Keywords: Bangka, conservation status, molecular identification, Rhina ancylostoma, Shark ray 


\section{PENDAHULUAN}

Pari Hiu (Rhinidae) merupakan jenis pari yang memiliki nilai ekonomis tinggi, terutama bagian siripnya. Harga sirip pari lebih tinggi dibanding dengan sirip ikan kelompok elasmobranchii lainnya. Meskipun bagi sebagian nelayan ikan pari hanyalah sebagai usaha tangkapan sampingan (by catch), akan tetapi produksi yang dihasilkan menunjukan nilai yang signifikan. Menurut catatan FAO, Indonesia berada diposisi teratas yang banyak memproduksi hiu dan pari setiap tahunnya [1][2]. Tingginya aktivitas penangkapan Pari Hiu (Rhinidae) berpengaruh besar terhadap populasi secara lokal maupun nasional, yang memengaruhi keseimbangan ekosistem laut. Hal tersebut didukung dengan karakteristik ikan pari yang memiliki kemampuan reproduksi rendah dan membutuhkan waktu yang lama, pertumbuhan yang lambat serta resiko kematian yang tinggi [1][3].

Terbatasnya informasi basis data yang berhubungan dengan ikan pari terutama Pari Hiu menurunkan pengawasan ataupun peraturan yang mengatur jumlah tangkapan produksi. Sehingga kondisi ini dikhawatirkan berdampak terhadap kelangsungan hidup Pari Hiu di Indonesia khususnya di Kepulauan Bangka Belitung. Salah satu basis data penting yang harus dilakukan yaitu identifikasi akurat untuk spesies ikan Pari Hiu yang didaratkan di Pulau Bangka sebagai acuan dalam penentuan status konservasi. Identifikasi konvensional umumnya sulit dilakukan pada sampel ikan pari yang memiliki nilai ekonomis tinggi karena tidak dapat diamati secara detail di laboratorium, sehingga metode taksonomi molekuler (DNA barcoding) dapat membantu proses identifikasi karena hanya membutuhkan sedikit jaringan tubuh dari ikan pari tersebut. Selain itu dalam rangka mewujudkan hasil diskusi dalam Rumusan Simposium Hiu dan Pari di Indonesia ke-2 Tahun 2018 tentang "Penggunaan pendekatan genetik dan molekuler sebagai perangkat untuk investigasi dan inventarisasi keragaman genetik dan status populasi”, sehingga metode molekuler penting digunakan sebagai langkah untuk mengidentifikasi ikan Pari Hiu yang ditemukan.

Informasi tentang kajian mengenai identifikasi molekuler khusus Pari Hiu belum ada di Pulau Bangka. Kajian identifikasi molekuler untuk Pari Hiu dijumpai dalam jurnal internasional yang mengidentifikasi hiu dan pari yang tertangkap di Perairan Australia, dalam penelitiannya terdapat jenis Pari Hiu (Rhinidae) [4]. Selain itu, kajian Pari Hiu ditemukan dalam penelitian [5], dalam penelitiannya mengkaji tentang pengelolaan ikan hiu dan pari di Kepulauan Bangka Belitung dengan proses identifikasi morfologi ikan (bukan identifikasi molekuler), daerah tangkapan dan pemasaran ikan hiu dan pari tersebut.

Tujuan penelitian adalah untuk mengidentifikasi Pari Hiu secara molekuler (mtDNA). Gen pengkode protein yang digunakan untuk identifikasi spesies adalah gen Cytochrome c oxidase subunit I (COI). COI merupakan sekuen gen pendek yang dipilih diantara banyaknya gen yang digunakan sebagai gen standar identifikasi khusus untuk spesies berbasis DNA barcode [6]; tujuan kedua yaitu analisis filogenetik untuk rekonstruksi hubungan kekerabatan antara organisme; dan terakhir penentuan status konservasi dan perdagangan Pari Hiu yang didaratkan di Pulau Bangka.

\section{METODE PENELITIAN}

\section{Waktu dan Tempat}

Penelitian dilaksanakan pada bulan April Agustus 2019. Pengambilan sampel Pari Hiu diambil dari sumber pendaratan yang potensial di Pulau Bangka yaitu Pelabuhan Perikanan Nusantara (PPN) Sungailiat, Tempat Pelelangan Ikan (TPI) Ketapang - Kota Pangkalpinang dan Tempat Pelelangan Ikan (TPI) Kurau Kabupaten Bangka Tengah. Pengambilan sampel dilakukan dengan mengambil sebagian kecil potongan organ tubuh ikan pari tersebut untuk selanjutnya dilakukan proses identifikasi dan analisis molekuler di laboratorium.

\section{Identifikasi Molekuler}

Identifikasi molekuler dimulai pada proses destruksi jaringan dan purifikasi DNA Pari Hiu. Ekstraksi dan purifikasi DNA menggunakan kolom silika yang terdiri dari 3 tahap penting, 
diantaranya binding, washing dan Elution dengan mengikuti prosedur DNeasy Blood and Tissue Kit. Bagian dari tubuh ikan yang akan diekstraksi, yaitu potongan daging dengan berat 5-10 mg. Hasil proses ekstraksi kemudian disimpan pada suhu $-20^{\circ} \mathrm{C}$. Amplifikasi gen COI (Cytochrome $c$ Oxidase Subunit I) menggunakan primer forward FishF2_t1 dan primer reverse FishR2_t1 [7]. DNA amplifikasi melalui perlakuan temperatur (yang telah dimodifikasi oleh peneliti): denaturasi awal pada suhu $95^{\circ} \mathrm{C}$ selama 1 menit, denaturasi pada $95^{\circ} \mathrm{C}$ selama 15 detik, annealing pada $48-54^{\circ} \mathrm{C}$ selama 15 detik, dan extension pada $72^{\circ} \mathrm{C}$ selama 10 detik (35 siklus), dan final extension pada $72^{\circ} \mathrm{C}$ selama 10 menit [8].

Campuran bahan yang digunakan adalah GoTaq ${ }^{\circledR G r e e n}$ Master Mix $(25-50 \mu 1)$, primer forward $(0,5-5 \mu \mathrm{l})$, primer reverse $(0,5-5 \mu \mathrm{l})$, ekstrak DNA (1-5 $\mu \mathrm{l})$, dan Nuclease-Free Water $(50 \mu \mathrm{l})$. Bahan-bahan tersebut dimasukkan ke dalam eppendorf kemudian di running sesuai dengan perlakuan suhu di atas. Elektroforesis, proses bergeraknya molekul bermuatan pada suatu medan listrik yang digunakan untuk pemisahan makromolekul (seperti protein dan asam nukleat). Posisi molekul yang memisah pada gel dapat dideteksi dengan pewarnaan atau autoradiografi, ataupun dilakukan kuantifikasi dengan densitometer [6]. Proses sekuensing DNA dilakukan untuk analisis sekuens DNA amplikon hasil PCR dengan automated DNA sequencer setelah dilakukan purifikasi terlebih dahulu dan dilakukan tahap cycle sequencing menggunakan kit Big Dye Terminator $^{\mathrm{R}}$ v3.1 (Applied Biosystem). Hasil dari sekuensing dilakukan homologi BLAST dengan memasukkan kode genetik ke dalam GenBank.

\section{Penyusunan DNA Consensus}

Penyusunan DNA consensus menggunakan software MEGA7, yang meliputi; proses trimming, reverse compliment dan alignment. Proses alignment dilakukan dengan bantuan software MUSCLE yang terintegrasi dalam program MEGA7 [9]. Sekuens yang telah melalui proses alignment, selanjutnya dicocokan ke database nukleotida yang terdapat pada situs database nukleotida secara online, yaitu situs GenBank National Center for Biotechnology Information. Sekuens DNA consensus dicocokkan ke database genbank dengan menggunakan fasilitas nucleotida blast yang terintegrasi di laman GenBank [10].

\section{Analisis Filogenetik}

Analisis filogenetik yang digambarkan sebagai klasifikasi secara taksonomi dari organisme berdasarkan pada filogeni sampel dan merupakan bagian integral dari ilmu pengetahuan yang sistematik dan mempunyai tujuan untuk menentukan filogeni dari organisme berdasarkan pada karakteristik sampel tersebut [11]. Berdasarkan analisis, sekuen yang mempunyai kedekatan dapat diidentifikasi dengan menempati cabang yang bertetangga pada pohon. Ketika keluarga gen ditemukan dalam organisme atau kelompok organisme, hubungan filogenetika diantara gen dapat memprediksikan kemungkinan yang satu mempunyai fungsi yang ekuivalen [12][13].

\section{Penentuan Status Konservasi}

Hasil yang diperoleh dari identifikasi molekuler dianalisis status konservasinya dengan menggunakan IUCN (International Union for Conservation of Nature and Natural Resources). Tujuan didirikannya IUCN adalah untuk membantu komunitas di seluruh dunia dalam konservasi alam. Kategori status IUCN Red List merupakan kategori yang digunakan oleh IUCN dalam melakukan klasifikasi terhadap spesies-spesies berbagai makhuk hidup yang terancam kepunahan. Penentuan status konservasi ikan Pari Hiu yang didapatkan pada penelitian ini adalah mengacu pada Pedoman Daftar Merah (Red List) IUCN. Selain itu, status perdagangan Pari Hiu pada penelitian ini dianalisis menggunakan CITES atau Convention on International Trade in Endangered Species of Wild Fauna and Flora. Fokus utama CITES adalah memberikan perlindungan pada spesies tumbuhan dan satwa liar terhadap perdagangan internasional yang 
tidak sesuai dengan ketentuan yang berlaku, yang dapat membahayakan kelestarian dari tumbuhan dan satwa liar tersebut.

\section{HASIL DAN PEMBAHASAN}

\section{Pengukuran Konsentrasi dan Kemurnian DNA}

Hasil ekstraski berupa $100 \mu \mathrm{l}$ DNA template Pari Hiu kemudian dilakukan pengukuran konsentrasi dan kemurnian DNA menggunakan

Nano-volume

UV

Quantification. Pita ganda DNA dapat menyerap cahaya UV pada $260 \mathrm{~nm}$, sehingga kemurnian DNA dapat diukur dengan menghitung nilai absorbansi $260 \mathrm{~nm}$ dibagi dengan nilai absorbansi 280 (A260/A280). Berikut analisa kemurnian DNA sampel ikan Pari Hiu:

Tabel 1. Hasil pengukuran konsentrasi dan kemurnian DNA sampel Pari Hiu

\begin{tabular}{lccccccccc}
\hline No & $\begin{array}{c}\text { Sample } \\
\text { Name }\end{array}$ & $\begin{array}{c}\text { Nucleic Acid } \\
\text { Conc. }\end{array}$ & Unit & A260 & A280 & $\mathbf{2 6 0 / 2 8 0}$ & $\mathbf{2 6 0 / 2 3 0}$ & $\begin{array}{c}\text { Sample } \\
\text { Type }\end{array}$ & Factor \\
\hline 1 & Blank & 0.1 & $\mathrm{ng} / \mu \mathrm{l}$ & -0.024 & -0.031 & 0.80 & 0.98 & DNA & 50.00 \\
2 & $\mathrm{~S} 2$ & 103 & $\mathrm{ng} / \mu \mathrm{l}$ & 2.061 & 1.811 & 1.14 & 0.24 & DNA & 50.00 \\
3 & $\mathrm{P} 2$ & 30.7 & $\mathrm{ng} / \mu \mathrm{l}$ & 0.614 & 0.210 & 2.93 & -0.59 & DNA & 50.00 \\
4 & $\mathrm{~K} 2$ & 11.1 & $\mathrm{ng} / \mu \mathrm{l}$ & 0.222 & 0.036 & 5.83 & -0.16 & DNA & 50.00 \\
\hline
\end{tabular}

Keterangan: S2: Sampel Pari Hiu dari PPN Sungailiat - Kabupaten Bangka, P2: Sampel Pari Hiu dari TPI Ketapang - Kota Pangkalpinang, K2: Sampel Pari Hiu dari TPI Kurau - Kabupaten Bangka

\section{Polymerase Chain Reaction (PCR) dan Elektroforesis}

PCR merupakan teknik perbanyakan DNA target secara in vitro. Komponen PCR terdiri dari: DNA template, yaitu fragmen yang akan dilipatgandakan; Oligonukleotida primer, yaitu suatu sekuen oligonukleotida pendek (1525 nukleotida) yang digunakan untuk mengawali sintesis rantai DNA; deoksiribinukleotida trifosfat (dNTP), terdiri dari dATP, dCTP, dGTP, dTTP; dan enzim DNA polymerase. Amplifikasi gen COI (Cytochrome c Oxidase Subunit I) menggunakan primer forward FishF2_t1 dan primer reverse FishR2_t1. Hasil PCR dan elektroforesis menunjukan adanya pita DNA pada masing-masing lintasan sampel DNA Pari Hiu yang teramati pada posisi panjang amplikon sekitar 600-700 bp dengan menggunakan ukuran $1 \mathrm{~kb}$ DNA ladder sebagai pembanding (Gambar 1).

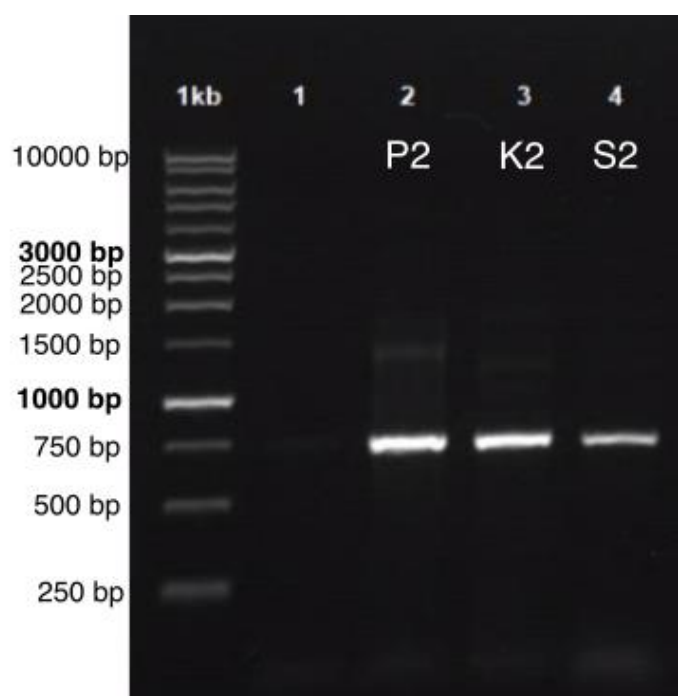

Gambar 1. Hasil amplifikasi gen COI sampel ikan Pari Hiu dengan gel agarose $1 \%$

Keterangan:

P2: Sampel Pari Hiu dari TPI Ketapang

K2: Sampel Pari Hiu dari TPI Kurau

S2: Sampel Pari Hiu dari PPN Sungailiat

\section{Hasil Sekuensing DNA Pari Hiu}

Hasil sekuensing tiga sampel Pari Hiu untuk sampel K2 dan P2 diperoleh urutan basa 678 kode DNA dan untuk sampel S2 diperoleh 685 kode DNA (Tabel 2). 
Table 2. Urutan basa nukleotida ikan hiu >3648713_S2_Fish

TTTGATCTTTGGTGCTTGAGCAGGAATAGTTGGTACT GGTCTAAGTTTACTTATTCGAACAGAGCTTAGCCAAC CCGGAACACTTCTTGGAGATGACCAAATCTATAATGT AGTTGTAACAGCCCATGCCTTCGTAATGATTTTCTTC ATAGTCATGCCAATCATAATTGGAGGGTTTGGTAATT GATTAATTCCTTTAATAATTGGCGCCCCAGACATAGC ATTCCCACGAATAAATAATATAAGCTTCTGATTGTTA CCTCCATCATTCCTTCTTTTATTAGCCTCTGCTGGAGT TGAAGCTGGAGTCGGAACAGGTTGAACTGTATACCC CCCACTTGCTGGTAACCTCGCCCATGCTGGAGCCTCC GTAGACTTAGCCATTTTTTCATTACATTTAGCCGGGG TATCCTCTATCCTAGCATCCATTAATTTTATTACAACA ATCATTAACATAAAACCCCCAGCAATCTCTCAGTATC AGACACCTTTATTTGTGTGGTCAATTCTTGTAACAAC CGTTCTTCTACTACTCTCATTACCTGTACTAGCAGCG GGTATTACCATACTCCTCACAGATCGAAATCTTAATA CTACTTTCTTTGACCCAGCAGGAGGCGGAGATCCAAT CCTTTATCAACATTTATTCTGATTCTTCGGTCACCCTG AAGTGTCATAGCTGTTT

$>3617659$ K2_Fish

ATTTGATCTTTGGTGCTTGAGCAGGAATAGTTGGTAC TGGTCTAAGTTTACTTATTCGAACAGAGCTTAGCCAA CCCGGAACACTTCTTGGAGATGACCAAATCTATAATG TAGTTGTAACAGCCCATGCCTTCGTAATGATTTTCTT CATAGTCATGCCAATCATAATTGGAGGGTTTGGTAAT TGATTAATTCCTTTAATAATTGGCGCCCCAGACATAG CATTCCCACGAATAAATAATATAAGCTTCTGATTGTT ACCTCCATCATTCCTTCTTTTATTAGCCTCTGCTGGAG TTGAAGCTGGAGTCGGAACAGGTTGAACTGTATACC CCCCACTTGCTGGTAACCTCGCCCATGCTGGAGCCTC CGTAGACTTAGCCATTTTTTCATTACATTTAGCCGGG GTATCCTCTATCCTAGCATCCATTAATTTTATTACAAC AATCATTAACATAAAACCCCCAGCAATCTCTCAGTAT CAGACACCTTTATTTGTGTGGTCAATTCTTGTAACAA CCGTTCTTCTACTACTCTCATTACCTGTACTAGCAGC GGGTATTACCATACTCCTCACAGATCGAAATCTTAAT ACTACTTTCTTTGACCCAGCAGGAGGCGGAGATCCA ATCCTTTATCAACATTTATTCTGATTCTTCGGTCACCC TGAAGTGTCAT

>3617667_P2_Fish

TTGATCTTTGGTGCTTGAGCAGGAATAGTTGGTACTG GTCTAAGTTTACTTATTCGAACAGAGCTTAGCCAACC CGGAACACTTCTTGGAGATGACCAAATCTATAATGTA GTTGTAACAGCCCATGCCTTCGTAATGATTTTCTTCA TAGTCATGCCAATCATAATTGGAGGGTTTGGTAATTG ATTAATTCCTTTAATAATTGGCGCCCCAGACATAGCA TTCCCACGAATAAATAATATAAGCTTCTGATTGTTAC CTCCATCATTCCTTCTTTTATTAGCCTCTGCTGGAGTT GAAGCTGGAGTCGGAACAGGTTGAACTGTATACCCC CCACTTGCTGGTAACCTCGCCCATGCTGGAGCCTCCG TAGACTTAGCCATTTTTTCATTACATTTAGCCGGGGT ATCCTCTATCCTAGCATCCATTAATTTTATTACAACA ATCATTAACATAAAACCCCCAGCAATCTCTCAGTATC AGACACCTTTATTTGTGTGGTCAATTCTTGTAACAAC CGTTCTTCTACTACTCTCATTACCTGTACTAGCAGCG GGTATTACCATACTCCTCACAGATCGAAATCTTAATA CTACTTTCTTTGACCCAGCAGGAGGCGGAGATCCAAT CCTTTATCAACATTTATTCTGATTCTTCGGTCACCCTG AAGTGT

Hasil uji sekuensing berupa urutan basa dianalisis menggunakan database urutan bilogis sentral, yakni GenBank yang berada di bawah NCBI (National Center for Biotechnology Information), Bethesda, Maryland, Amerika. Database tersebut merupakan database primer yang menampung semua urutan DNA yang didepositkan oleh para peneliti dari seluruh dunia. Teknik pencarian berdasarkan kekerabatan antar data menggunakan program pencari yang terdapat dalam database tersebut. Dua program yang banyak digunakan adalah Basic Local Alignment Search Tool (BLAST) dan FASTA. Dari program tersebut diperoleh bahwa sekuensing sampel ikan Pari Hiu dengan kode sampel S2, K2 dan P2 teridentifikasi jenis Rhina ancylostoma (Bloch and Schneider, 1801) (Bowmouth Guitarfish, Shark Ray) [14] dengan tingkat kemiripan sebesar $100 \%$.

\section{Filogenetik Pari Hiu}

Hasil analisis filogenetik sampel Pari Hiu S2, K2 dan P2 dengan menggunakan MEGA7 adalah sebagai berikut:

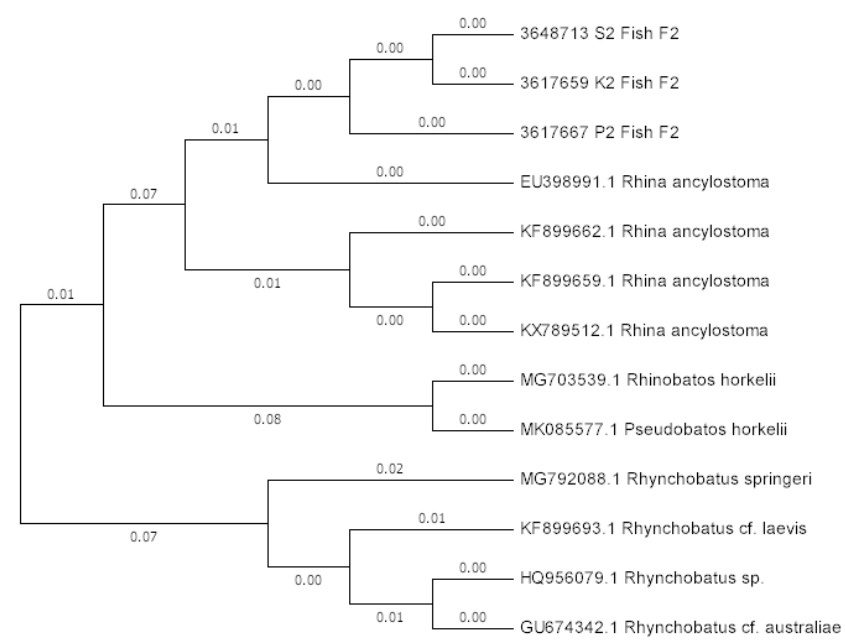

Gambar 2. Pohon kekerabatan (filogenetik) sampel ikan Pari Hiu (kode sampel S2, K2 dan P2) yang didaratkan di Pulau Bangka

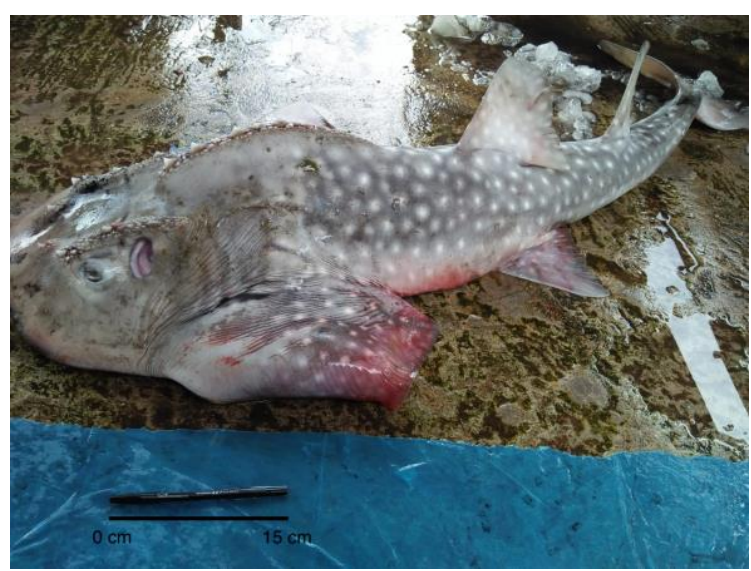

Gambar 3. Rhina ancylostoma (Shark Ray) yang didaratkan di PPN Sungailiat 


\section{Status Konservasi}

Berdasarkan data IUCN Red List, spesies Rhina ancylostoma masuk dalam kategori Critically Endangered (CR) dan berdasarkan status perdagangannya, pada pertemuan $\mathrm{CoP}$ ke 18 di Geneva, Agustus 2019, CITES telah menambahkan Wedgefishes (Family Rhinidae) ke dalam Apendix II.

\section{Pembahasan}

Identifikasi molekuler dengan menggunakan gen COI mtDNA adalah salah satu cara yang akurat untuk mengidentifikasi ikan ketika sampel spesies tersebut tidak dapat diidentifikasi morfologinya secara utuh. Metode ini telah digunakan oleh peneliti lain untuk taksonomi, analisis filogeografi dan populasi, deteksi telur dan larva serta aplikasi industri [15][16]. Selain itu, identifikasi molekuler juga dapat digunakan sebagai informasi untuk mengetahui hubungan filogenetik ikan hiu dan pari [17]. Hal ini yang dilakukan pada penelitian ikan Pari Hiu di Pulau Bangka, metode molekuler digunakan sebagai langkah untuk mengidentifikasi ikan Pari Hiu beserta filogenetiknya. Dari tiga sampel Pari Hiu yang terkumpul, diperoleh hasil ekstraksi DNA dengan kemurnian antara 1.14 - 5.83 (Tabel 1). Menurut Fatchiyah et al. (2011) [6], rekomendasi nilai kemurnian DNA berkisar antara 1.8 - 2.0. Jika nilai yang dihasilkan $<1.8$ terdapat kontaminasi protein dalam DNA dan jika nilai yang diperoleh $>2.0$ terdapat kemungkinan adanya kontaminasi garam saat proses purifikasi. Dalam hal ini, salah satu cara yang dapat dilakukan untuk mengurangi kontaminasi tersebut dengan melakukan pengenceran pada DNA template.

Hasil proses PCR sampel Pari Hiu menunjukan gen COI teramplifikasi dengan panjang amplikon untuk sampel K2 dan P2 678 kode DNA dan untuk sampel S2 diperoleh 685 kode DNA (Gambar 1 dan Tabel 2). Ukuran panjang amplifikasi Pari Hiu hasil penelitian ini sama dengan penelitian yang dilakukan oleh Ward et al (2008) [16] yang memperoleh ukuran urutan basa sekitar $650-700$ bp untuk jenis sampel Pari Hiu yang sama yang tertangkap di Perairan Australia. Hasil pengurutan DNA gen COI selanjutnya disunting menggunakan perangkat lunak MEGA7. DNA consensus masing-masing spesimen telah disusun dengan melakukan pemotongan basa berkualitas kurang baik. Masing-masing spesimen hasil penyusunan DNA consensus telah diubah ke dalam format FASTA dan mendapatkan sejumlah urutan nukleotida, selanjutnya urutan nukleotida dicocokkan dengan menggunakan program BLAST yang terintegrasi pada laman GanBank (NCBI). Hasil BLAST sekuens sampel Pari Hiu kode $\mathrm{S} 2$, P2 dan K2 menunjukan teridentifikasi jenis Rhina ancylostoma (Bowmouth Guitarfish, Shark Ray) dengan tingkat kemiripan sekuen sebesar $100 \%$. Presentase tingkat kemiripan sekuens yang berada pada nilai $\geq 99 \%$ menunjukkan bahwa spesies yang dibandingkan merupakan spesies yang sama [18].

Rhina ancylostoma (Shark Ray) merupakan jenis ikan pari dengan nama lokal di Pulau Bangka oleh para nelayan dan masyarakat sekitar disebut sebagai Hiu Mejan. Rhina ancylostoma dapat ditemukan pada habitat dasar perairan pantai dan karang, tetapi kedalamannya belum diketahui. Sistem reproduksi secara vivipar dengan ketergantungan embrio pada kuning telur. Jenis ikan ini memiliki kebiasaan makanan utama berupa krustasea dan moluska. Beberapa ciri umum Rhina ancylostoma memiliki letak pangkal sirip punggung pertama berada di depan pangkal sirip perut, bentuk sirip ekor seperti sabit dan hampir simetris; ukuran moncong tebal, membundar lebar; tidak ada selaput atau tonjolan kulit pada tepi belakang spirakel; lingkaran mata, bagian tengah tubuh dan pundak memiliki guratan-guratan yang terdiri dari duri-duri atau gerigi yang kuat (thorns) [19](Gambar 3).

Pohon kekerabatan (filogenetik) ketiga sampel ikan Pari Hiu (kode sampel S2, K2 dan P2) yang didaratkan di Pulau Bangka memiliki urutan sekuen yang identik dengan Rhina ancylostoma dan berada dalam cluster yang sama (Gambar 2). Proses penyusunan filogenetik dalam penelitian ini menggunakan metode Neighbor-Joining [20]. Jarak evolusioner dihitung dengan menggunakan metode Maximum Composite Likelihood [21] dan berada dalam satuan jumlah subtitusi dasar per site. Analisis untuk menentukan bagaimana keluarga tersebut diturunkan selama proses evolusi dapat dilihat dari analisis filogenetik. Hubungan evolusi diantara sekuen digambarkan dengan menempatkan sekuen sebagai cabang luar dari sebuah pohon. Hubungan cabang pada bagian dalam pohon merefleksikan tingkat dimana sekuen yang berbeda saling 
berhubungan. Pohon filogenetika memberi informasi tentang pengklasifikasian populasi berdasarkan hubungan evolusionernya. Dalam rekonstruksi pohon filogenetika, data molekul lebih banyak dipakai karena dianggap lebih stabil dalam proses evolusi dibandingkan dengan data morfologi [22].

Berdasarkan status konservasinya, spesies Rhina ancylostoma masuk dalam kategori Critically Endangered (CR) [23]. Status konservasi tersebut ditentukan oleh badan internasional IUCN (International Union for Conservation of Nature and Natural Resources) yang fokus pada usaha konservasi hiu dan pari (Elasmobranchii). Critically Endangered (sangat terancam) adalah status konservasi yang diberikan kepada spesies yang menghadapi risiko kepunahan di waktu dekat. Tahun 2016 lalu, status konservasi untuk Rhina ancylostoma masih berada pada level Vulnerable (VU). Vulnerable (VU) adalah status konservasi yang diberikan kepada spesies yang sedang menghadapi risiko kepunahan di alam liar pada waktu yang akan datang. Selain itu, berdasarkan status perdagangannya, pada pertemuan Conference of Parties (CoP) ke 18 di Geneva, 17-28 Agustus 2019, CITES telah menambahkan Wedgefishes (Family Rhinidae) ke dalam Apendiks II [24]. Apendiks II adalah daftar spesies yang tidak terancam kepunahan, tapi mungkin terancam punah bila perdagangan terus berlanjut tanpa adanya pengaturan.

Melihat peningkatan status konservasi dan status perdagangan untuk ikan Pari Hiu, maka perlu dilakukannya konservasi dan pengelolaan yang spesifik. Pengelolaan tersebut tidak dapat dilakukan oleh satu institusi saja melainkan kerjasama dengan berbagai pihak menggunakan pendekatan co-management. Pendekatan comanagement mewajibkan pemerintah membuat regulasi yang lebih ketat dalam teknis pengelolaannya. Disisi lain, perlu adanya sosialisasi terhadap pihak swasta agar mengurangi tingkat permintaan konsumsi sirip Pari Hiu atau sosialisasi dengan melarang menjual sup sirip Pari Hiu. Sedangkan masyarakat perlu secara bertahap ditingkatkan kesadarannya untuk tidak menangkap Pari Hiu, tetapi tetap didorong untuk meningkatkan konsumsi jenis ikan lainnya yang tetap tergolong ekonomis penting. Semua upaya ini harapannya dapat memberikan kontribusi dalam mempertahankan keberlangsungan populasi Ikan Pari Hiu Rhina ancylostoma di perairan.

\section{KESIMPULAN}

Hasil pencocokan karakter nukleotida gen COI dilakukan dengan menggunakan program BLAST yang terintegrasi pada laman GenBank dan menunjukkan bahwa ketiga sampel ikan Pari Hiu tersebut teridentifikasi sebagai spesies Rhina ancylostoma (Bowmouth Guitarfish, Shark Ray) dengan tingkat kemiripan sebesar 100\%. Berdasarkan data IUCN Red List, spesies Rhina ancylostoma masuk dalam kategori Critically Endangered (CR) dan berdasarkan status perdagangannya, pada pertemuan CoP ke 18 di Geneva, Agustus 2019, CITES telah menambahkan Wedgefishes (Family Rhinidae) ke dalam Apendix II.

\section{UCAPAN TERIMA KASIH}

Terima kasih kepada Hibah Penelitian Dosen Pemula, Kementerian Riset, Teknologi dan Pendidikan Tinggi Republik Indonesia. Ucapan terima kasih kepada Lembaga Penelitian dan Pengabdian Masyarakat (LPPM) dan Jurusan Manajemen Sumberdaya Perairan Universitas Bangka Belitung.

\section{DAFTAR PUSTAKA}

[1] Stevens J.D., R. Bonfil, N.K. Dulvy, and P.A. Walker. 2000. The Effects of Fishing on Sharks, Rays and Chimaeras (Chondrichthyans), and the Implications for Marine Ecosystem. ICES Journal of Marine Science, 57:476-494.

[2] Traffic. 2002. A CITES Priorities: Sharks and the Twelfth Meeting of the Conference of the Parties to CITES, Santiago Chile. IUCN and TRAFFIC Briefing document, page 2. (Online) Available

at: http://www.traffic.org/news/SharksCoP1 2.

[3] Camhi M., S. Fowler, J. Musick, A. Brautigam, and S. Fordham. 1998. Sharks and their relatives, ecology and conservation. Occasional Paper of the IUCN Species Survival Commission No.20. IUCN, Gland, Switzerland and Cambridge, UK. 39 p.

[4] Holmes B.H., S. Dirk, and D.W. Robert. 2009. Identification of Shark and Ray 
Fins using DNA Barcoding. Fisheries Research, 95: 280-288.

[5] Kurniawan A., H. Fahrian, P. Aji, F. Muhammad, N. Aditya, dan P. Jumadi. 2014. Pengelolaan Perikanan Hiu di Kepulauan Bangka Belitung. Mitra Bahari vol. 8 No. 2. ISSN. 0216-4841. 25-33.

[6] Fatchiyah, L.A. Estri, W. Sri, dan R. Sri. 2011. Biologi Molekular - Prinsip Dasar Analisis. Erlangga, Jakarta. pp. 8-48.

[7] Ward R.D., T.S. Zemlak, B.H. Innes, P.R. Last, and P.D.N. Hebert. 2005. DNA barcoding Australia's fish species. Philosophical Transactions of the Royal Society of London. Series B, Biological Sciences.

[8] Eugene H.K.W., S.S. Mahmood, and H.H. Robert. 2009. Identifying Sharks with DNA Barcodes: Assessing the Utility of a Nucleotide Diagnostic Approach. Molecular Ecology Resources (Suppl. 1). 243-256. doi: 10.1111/j.17550998.2009.02653.x.

[9] Tamura K., G. Stecher, D. Peterson, A. Filipski, and S. Kumar. 2013. MEGA 6: Molecular Evolutionary Genetics Analysis version 6.0. [Computer software]. Molecular Biology and Evolution. 30:2725-2729.

[10] Claveire J.M., and C. Notredame. 2003. Bioinformatics for Dummies. Wiley Publishing, Indianapolis.

[11] Mount D.W. 2001. Phylogenetic prediction. In: Bioinformatic, Sequence and Genome Analysis. Cold Spring Harbor laboratory. New York Press. pp. $237-280$.

[12] Mcdonald J.H., and M. Kreitman. 1991. Adaptive protein evolution at the Adh locus in Drosophila. Nature. 351: $652-$ 654.

[13] Nielsen R., and Z. Yang. 1998. Likehood models for detecting positively selected amino acid sites and application to the
HIV-1 envelope gene. Genetics.148: 929 -936 .

[14] Bloch and Schneider. 1801. Rhina ancylostoma.

https://www.fishbase.in/summary/Rhinaancylostoma.

[15] Clarke S.C., J.E. Magnussen, D.L. Abercrombie, M.K. McAllister, and M.S. Shivji. 2006. Identification of shark species composition and proportion in the Hong Kong shark fin market based on molecular genetics and trade records. Conserv Biol 20: 201-211.

[16] Ward R.D., B.H. Holmes, W.T. White, and P.R. Last. 2008. DNA barcoding Australasian chondrichthyans: result and potential uses in conservation. Marine and Freshwater Research, 59: 57-71.

[17] Liu S.Y.V., C.L.C. Chan, O. Lin, C.S. $\mathrm{Hu}$, and C.A. Chen. 2013. DNA Barcoding of Shark Meats Identify Species Composition and CITES-Listed Species from the Markets in Taiwan. PLoS ONE 8(11): e79373. doi:10.1371/journal.pone.0079373.

[18] Drancourt M., C. Bollet, A. Carlioz, R. Martelin, J.P. Gayral, and D. Raoult. 2000. 16S ribosomal DNA sequence analysis of a large collection of environmental and clinical unidentifiable bacterial isolates. J Clin Microbiol. 38(10):23-30.

[19] White W.T., P.R. Last, J.D. Stevens, G.K. Yarsley, Fahmi, and Darmadi. 2006. Economycally important shark \& rays Indonesia. Australian Centre for International Agricultural Research, Canberra, Australia 2601. pp.198-199.

[20] Saitou N., and M. Nei. 1987. The neighbor-joining method: A new method for reconstructing phylogenetic trees. Molecular Biology and Evolution. 4:406425.

[21] Tamura K., M. Nei, and S. Kumar. 2004. Prospects for inferring very large phylogenies by using the neighborjoining method. Proceedings of the 
National Academy of Sciences (USA) 101:11030-11035.

[22] Dharmayanti N.L.P.I. 2011. Filogenetika Molekuler: Metode Taksonomi Organisme Berdasarkan Sejarah Evolusi. Wartazoa 12(1): $10 \mathrm{p}$.

[23] Kyne P.M., C.L. Rigby, Dharmadi, and R.W. Jabado. 2019. Rhina ancylostoma. The IUCN Red List of Threatened Species 2019: e.T41848A124421912. http://dx.doi.org/10.2305/IUCN.UK.2019 - 2.RLTS.T41848A124421912.en.

[24] CITES. 2019. Proposals for amendment of Appendices I and II - Eighteenth meeting of the Conference of the Parties. https://cites.org/eng/cop/18/prop/index.p hp. 